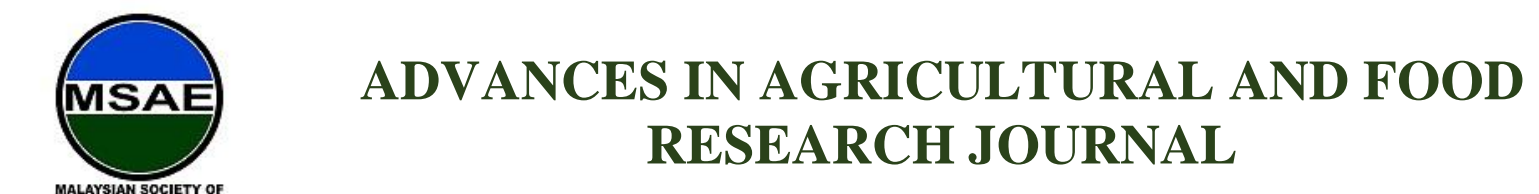

Original Research Article

\title{
Development of Efficient Processing System for Young Coconut Husk
}

Mohd Shahmihaizan Mat Jusoh', Wan Mohd Aznan Wan Ahamad ${ }^{2}$, Mohd Nadzim Nordin ${ }^{1}$, Md. Akhir Hamid $^{3}$, Sentoor Kumeran Govindasamy ${ }^{4}$, Zawayi Mat ${ }^{1}$, Norahshekin Abdul Rahman ${ }^{1}$

${ }^{1}$ Engineering Research Centre, MARDI Headquarters, 43400, Serdang, Selangor.

${ }^{2}$ Director General Office. MARDI Kota Bharu, 15710 Kota Bharu, Kelantan.

${ }^{3}$ Director General Office. MARDI Alor Setar, 06600 Alor Setar, Kedah.

${ }^{4}$ Industrial Crop Research Centre, MARDI Bagan Datuk, 36300 Sungai Sumun, Perak.

*Corresponding author: Mohd Shahmihaizan bin Mat Jusoh, Engineering Research Centre, MARDI Headquarters, 43400, Serdang, Selangor; shahmi@mardi.gov.my

\begin{abstract}
A processing system for young coconut husk was developed to cater abandoned young coconut husk in the coconut industry. This was a new invention as an alternative to the current coconut husk extractor in the coconut industry. There were several machines developed; 1) chopping machine, 2) young coconut husk extractor, 3) conveyor system, and 4) rotary screener. This processing system was introduced to ensure the abandoned young coconut husk can be extracted into fiber and cocopeat. The evaluation results showed that the average machine capacity of the young coconut husk extractor was $350.79 \mathrm{~kg} / \mathrm{hour}$ with the average weight ratio of unfiltered cocopeat and fiber produced at $70 \%$ and $30 \%$ respectively. The assessment of quality for fiber and cocopeat was done by using rotary screener that was equipped with 16 mesh nets. The result of cocopeat was $2.8 \%$ in the extracted fiber after extraction and filtration. Based on the analysis, cost of operation was RM 3.80/hr or equal to RM 668.70/month for the entire processing system. Total monthly income for machines owner was RM 52,923.30 and the ROI was $88.21 \%$. The results showed that the processing system was able to process the abandoned young coconut husk into fiber and cocopeat. Performance evaluation of each machine should be carried out in the future research to identify machines efficiency and durability.
\end{abstract}

Keywords: young coconut husk; chopping machine; coconut husk extractor; conveyor system; rotary screener; fiber; cocopeat; machine capacity; cost of operation; income, ROI

Received: $14^{\text {th }}$ September 2020

Accepted: $14^{\text {th }}$ October 2020

Citation: Mat Jusoh MS, Wan Ahamad WMA, Nordin MN, et al. Development of efficient processing system for young coconut husk. Adv

Published: $31^{\text {st }}$ October 2020 Agri Food Res J 2020; 1(2): a0000124. https://doi.org/10.36877/aafrj. a0000124

\section{Introduction}

Coconut was grown in more than 90 countries. In Malaysia, it was the fourth important crops in terms of acreage after oil palm, rubber and paddy (Christoper, 2018). The coconut 
industry has significant socio-economic implications as it provides the source of revenues and employment to households. In addition, it supports a number of vibrant small and medium coconut-based processing industries and exporters.

In Malaysia, 95\% of coconut growers were smallholders with an average yield of 5,966 $\mathrm{kg}$ coconuts/hectares in 2016. Coconut production was increased from 2016 to 2018 at 504,773 MT to 538,685 MT (Jabatan Pertanian Semenanjung Malaysia, 2018). The demand for young coconuts have begun to emerge with government initiatives, especially the Ministry of Agriculture in the 1990s through the encouragement of drinking young coconut water (Mohd Rashid et al., 2016). Young coconuts can be defined as at an immature stage, contains mainly water and a little jelly-like meat instead of the hard white flesh found in mature coconuts. The young coconut which was just as a non-commercialized beverage has turned out to be a very popular beverage among community. The higher market price and high market demand have attracted farmers to grow coconut.

Based on the report by Mohd Hafizudin et al. (2016) showed that $46.0 \%$ of consumers preferred Pandan varieties and $12.3 \%$ followed by Matag. Another $24 \%$ did not show a tendency to young coconut variety. A total of 32.12 million young coconuts per month were estimated to fulfill the demand based on the results of the study.

The increase in demand for young coconut has contributed to the increase in residual products such as coconut husk. Based on production in 2018, as much as $44 \%$ of coconut husk is unutilized and disposed in open field (Tafsir \& Mohd Hafizudin, 2018). There was no systematic disposal methods of coconut husk as they were thrown and burned openly and it can lead to pollution (Refs). The development of processing system for young coconut husk, to process the husk into value-added products such as cocopeat and fiber could overcome this pollution. This cocopeat can be sold at RM 7/bag or RM 1.40/kg while fiber can be sold at RM 1.20/kg (Mohd Zaffrie et al. 2018). There were several usages of cocopeat in the industry such as planting media in fertigation system while coir fiber can be processed into bed, pillow, car cushion, and dashboard.

Evaluation of the developed young coconut husk extractor and rotary screener had been carried out in previous research to identify its performance. It was able to improve the efficiency, quality and production of cocopeat and fiber. The capacity of the young coconut husk extractor was up to $514.9 \mathrm{~kg} /$ hour with the average weight ratio of unfiltered cocopeat and fiber produced at $65.4 \%$ and $34.6 \%$ respectively meanwhile the results of cocopeat quality evaluation have found only $5.7 \%$ fiber contained in the cocopeat mixture after extraction and filtration (Wan Mohd Aznan et al. 2019).

This paper explained the improvement of the system by developing all machineries involved in the processing line of young coconut husk extractions into fiber and cocopeat. The function of operation each machine was described clearly and cost of operation was explained in detail. 


\section{Materials and Methods}

\subsection{Machines Description and Operation}

All machines were developed and fabricated at Engineering Research Center, MARDI Serdang, Selangor. The fabricated processing line of young coconut husk was placed at Engineering Research Center Workshop, MARDI Serdang.

\subsubsection{Chopping machine}

A chopping machine as shown in Figure 1 was developed to cut the young husk into three pieces. It was developed to make sure all materials fed into young coconut husk extractor were standard in sizes. The chopping machine comprised of a $1.5 \mathrm{~kW}$ single phase electric motor, belt and pulley, two 12-inch blades, and a pusher drive. The pusher drive was designed to push and lock the young coconut husk into the rotating blades to cut it into three pieces. The rotating blades were powered by the electric motor.

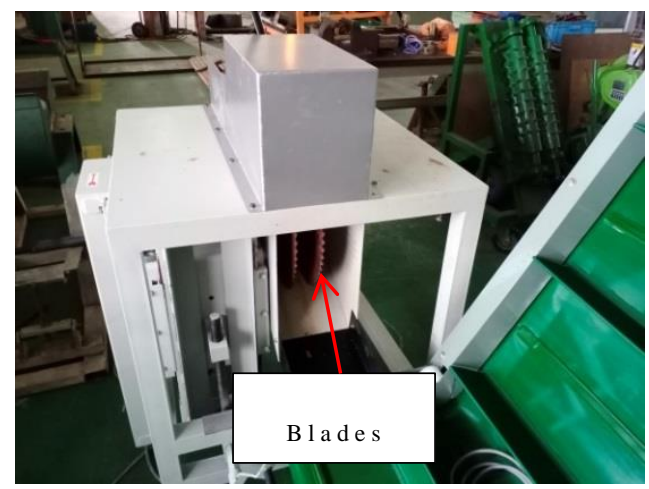

(a)

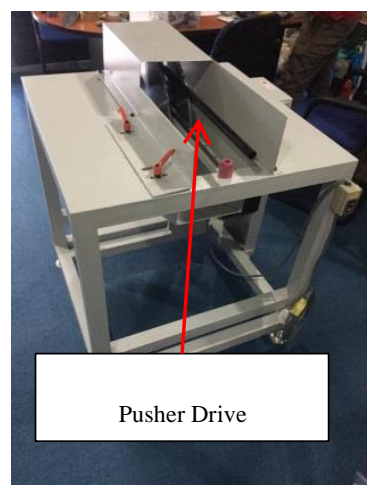

(b)

Figure 1. Chopping machine consist of: (a) Two blades; (b) Pusher drive.

\subsubsection{Conveyor 1}

A conveyor 1 as shown in Figure 2 was designed to transport the young coconut husk from the chopping machine to the young coconut husk extractor. The conveyor system was powered by a $0.75 \mathrm{~kW}$ electric motor and it was equipped with several partitions in the conveyor belt. 


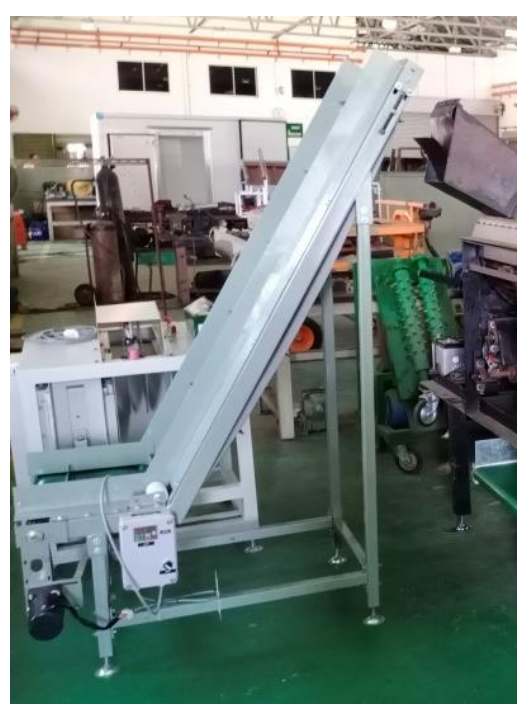

Figure 2. Conveyor 1 .

\subsubsection{Young coconut husk extractor}

A young coconut husk extractor as shown Figure 3 was designed to extract the young coconut husk into cocopeat and fiber. It was powered by a $6.8 \mathrm{~kW}$ diesel engine at $3000 \mathrm{rpm}$. It consists of two main function sections which were extraction mechanism and scraper mechanism. Both mechanisms were driven by the engine via belting mechanism. The extraction mechanism comprises of spike, cylinder drum, combing devices, filtering rods and fin plate whereas the scraper mechanism was installed under the filtering rod to smoothen the extraction operation by preventing the clogging of cocopeat. The scraper mechanism had been designed to operate continuously at speed of $0.03 \mathrm{~m} / \mathrm{s}$ through mechanical concepts. It was equipped with components such as speed reducer, chain and sprocket.

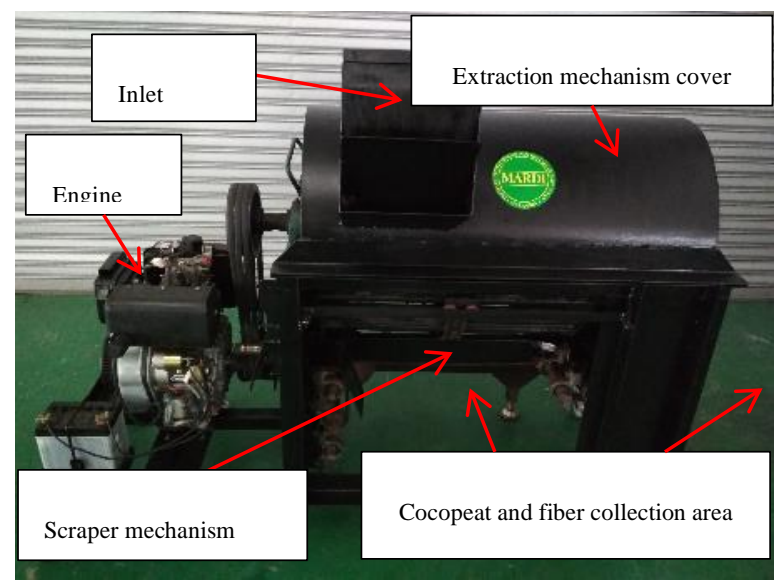

Figure 3. Young coconut husk extractor (Wan Mohd Aznan et al. 2019). 


\subsubsection{Conveyor 2}

A conveyor 2 as shown in Figure 4 was designed to transport the cocopeat to the collection area. The conveyor system was powered by a $0.75 \mathrm{~kW}$ electric motor.

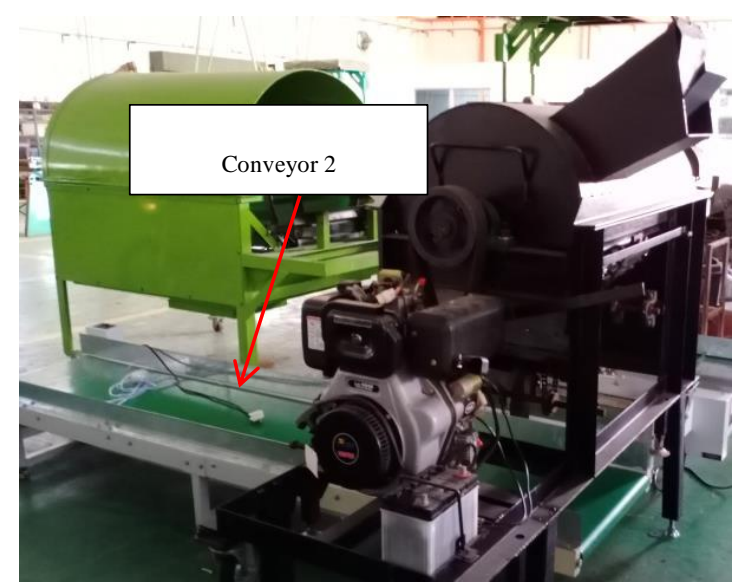

Figure 4. Conveyor 2

\subsubsection{Conveyor 3}

A conveyor 3 as shown in Figure 5 was designed to transport the fiber from the coconut husk extractor to the rotary screener. The conveyor system was powered by a $0.75 \mathrm{~kW}$ electric motor and it was equipped with several partitions in the conveyor belt.

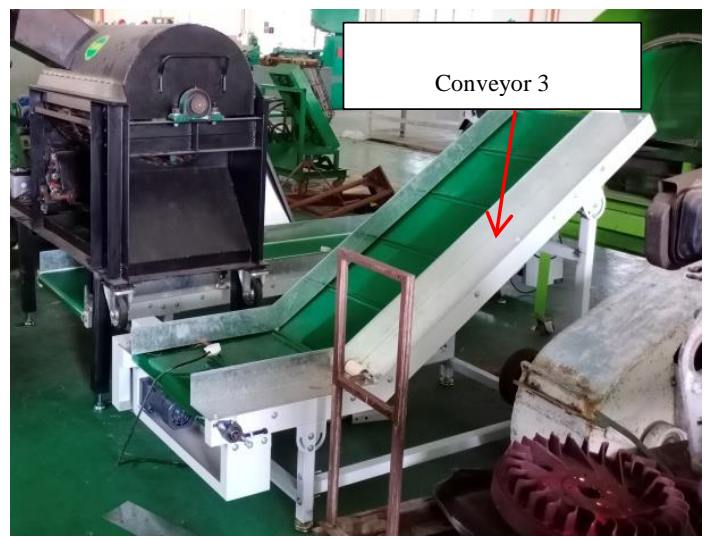

Figure 5. Conveyor 3.

\subsubsection{Rotary screener}

A rotary screener as shown in Figure 6 was designed to do filtering process of fiber and cocopeat. It was powered by a $0.75 \mathrm{~kW}$ electric motor and equipped with a 16 mesh of a plastic net. 


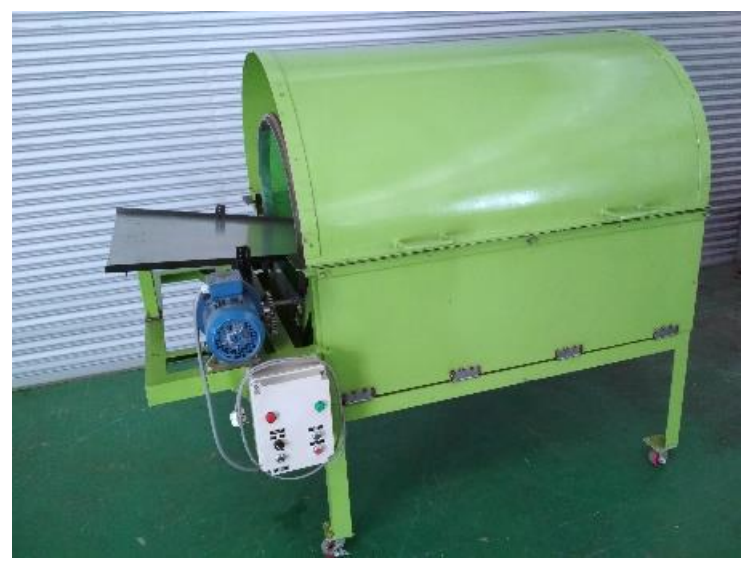

Figure 6. Rotary screener (Wan Mohd Aznan et al. 2019).

Figure 7 showed an efficient processing system for young coconut husk extractor that had been developed to produce better quality of cocopeat and fiber. It consists of chopping machine, conveyor 1, young coconut husk extractor, conveyor 2, conveyor 3 and rotary screener.

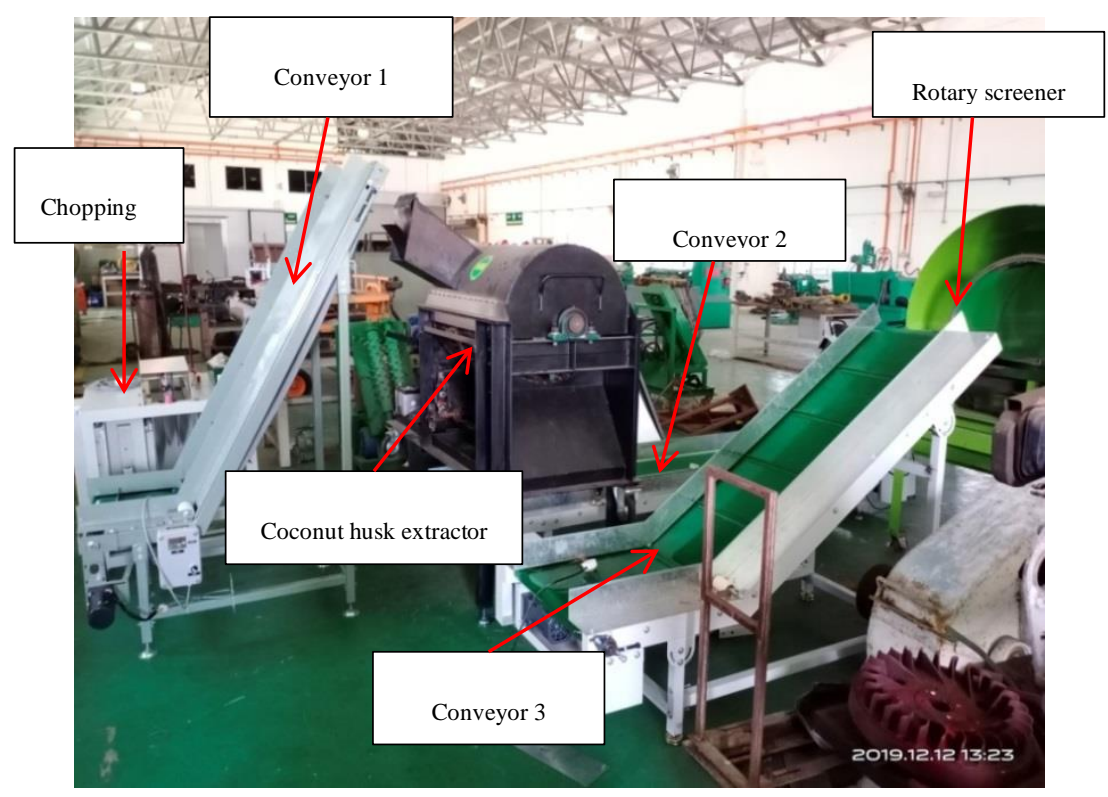

Figure 7. Efficient processing system for young coconut husk.

\subsection{Sample Preparation}

Performance assessment has been carried out on the machines and quality of the products produced which were cocopeat and fiber. The young coconut husk used in this machine evaluation was obtained from young coconut water stalls around Bandar Baru Bangi, Selangor. The experiment was done in MARDI Serdang, Selangor. The sample was dried up under open sunlight for a week before feeding into the extractor. 


\subsection{Extraction Process of Cocopeat and Fiber from Young Coconut Husk}

Operation of young coconut husk processing was repeated 20 times to determine the actual processing capacity of the machine. A total of $500 \mathrm{~kg}$ of young coconut husk was used for the extraction process. The outputs from the extractor were discharged and collected at different outlet path. Data such as the weight of the young coconut fiber, cocopeat and fiber produced and the processing period were recorded for calculation of machine capacity and gross product ratio. The machine capacity was calculated by using the following formula:

$$
\text { Machine Capacity }\left(\frac{\mathrm{kg}}{\mathrm{h}}\right)=\frac{\text { Total Weight of Material }(\mathrm{kg})}{\text { Duration of Processing }(\mathrm{h})}
$$

Meanwhile, the gross product ratio was calculated using the following equation:

$$
\begin{aligned}
& \text { Percentage of gross cocopeat weight (\%) } \\
& =\frac{\text { Weight of gross cocopeat }(\mathrm{kg})}{\text { Weight of gross cocopeat and fiber }(\mathrm{kg})} \times 100 \\
& \text { Percentage of gross fiber } \\
& =\frac{\text { Weight of gross fiber }(\mathrm{kg})}{\text { Weight of gross cocopeat and fiber }(\mathrm{kg})} \times 100
\end{aligned}
$$

Moisture content of the young coconut husk and cocopeat also recorded as a reference. Determination of moisture content for these materials was performed by using moisture balance AND MX-50. A total of $1 \mathrm{~g}$ sample was used for each assessment at a temperature of $105^{\circ} \mathrm{C}$ (Mani et al. 2004). Five samples for each material were used to perform this evaluation.

\subsection{Quality Evaluation of Cocopeat from Young Coconut Husk}

Quality evaluation of cocopeat produced via young coconut husk processing machine was performed for 5 samples to measure its product ratio. Cocopeat quality control was necessary to prevent the excessive content of fiber in the cocopeat mixture.

Total weight of filtered cocopeat and fiber were recorded for calculation of the weight ratio. Then, the cocopeat mixture that was filtered by using rotary screener was further analyzed in the laboratory by using a multi-layer shaker to determine the percentage of fiber that was still contained. The weight of fiber obtained from the analysis was recorded for computation of cocopeat and fiber ratio in ready-to-sell products. The percentage of the cocopeat and fiber is calculated using the following formula: 


$$
\begin{gathered}
\text { Percentage of cocopeat weight (\%) } \\
=\frac{\text { Weight of filtered cocopeat }(\mathrm{kg})}{\text { Weight of filtered cocopeat and fiber }(\mathrm{kg})} \times 100 \\
\text { Percentage of fiber weight }(\%) \\
=\frac{\text { Weight of filtered fiber }(\mathrm{kg})}{\text { Weight of filtered cocopeat and fiber }(\mathrm{kg})} \times 100
\end{gathered}
$$

\section{Results and Discussion}

\subsection{Machine Capacity of Young Coconut Husk Extractor}

Figure 8 showed results of machine capacity analysis for the young coconut husk processing machine. In average, the young coconut extractor was able to process $350.79 \mathrm{~kg} / \mathrm{h}$ of the husk.

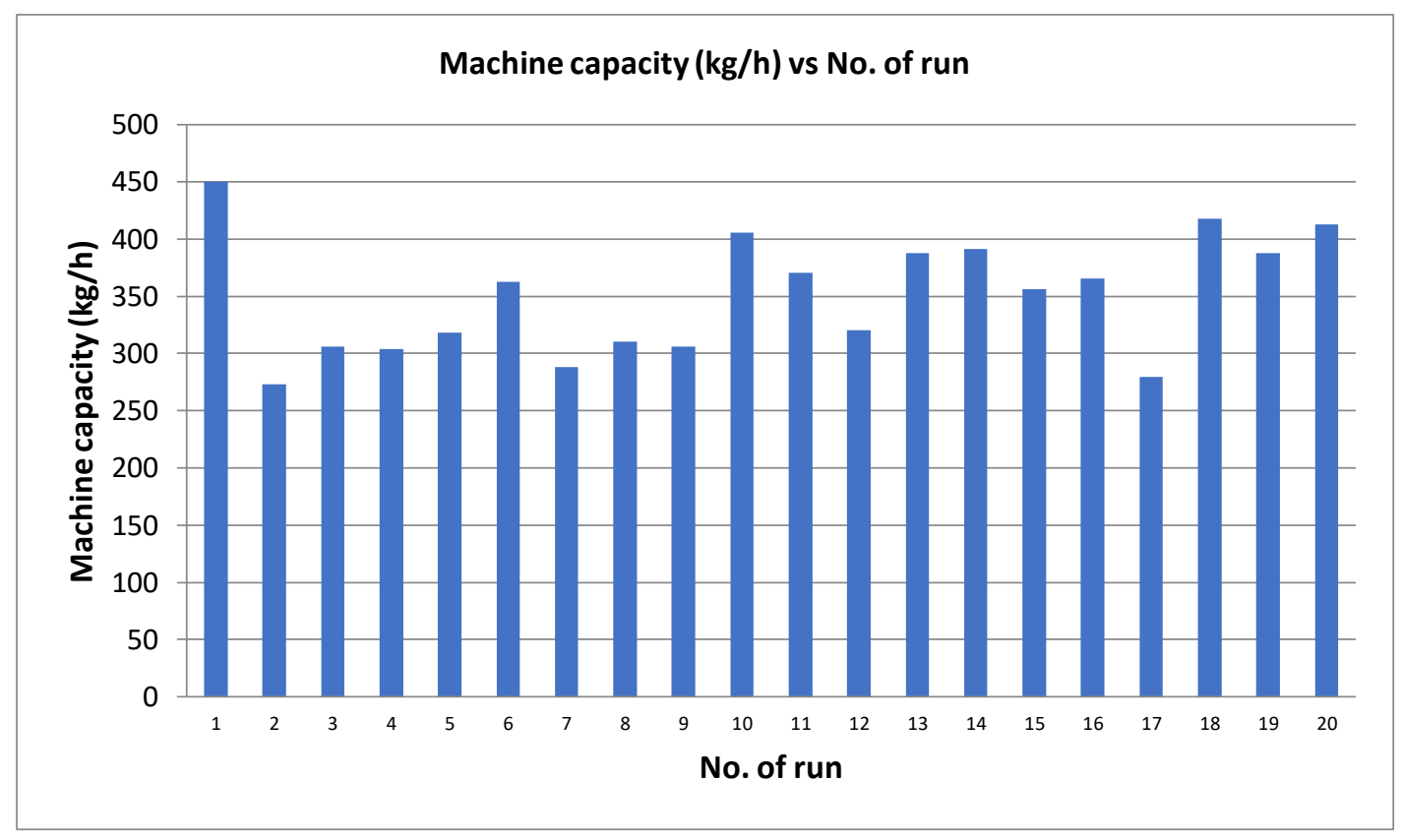

Figure 8. Machine capacity for young coconut husk extractor.

The factor that influenced this trend was young coconut husk moisture content. The moisture content of the collected young coconut husk varied from $70 \%$ to $90 \%$ due to the exposure of the material to the environment within a certain period of time before processing. Direct exposures to the sunlight and small cutting size have contributed to faster drying rates and reduced the moisture content of the husk (Onwuka \& Nwachukwu, 2013).

Figure 9 showed the result of gross product ratio for fiber and cocopeat that was extracted by the machine. The average result has indicated that the extracted husk contained $146.5 \mathrm{~kg}(30 \%)$ fiber and $350.5 \mathrm{~kg}(70 \%)$ cocopeat. 


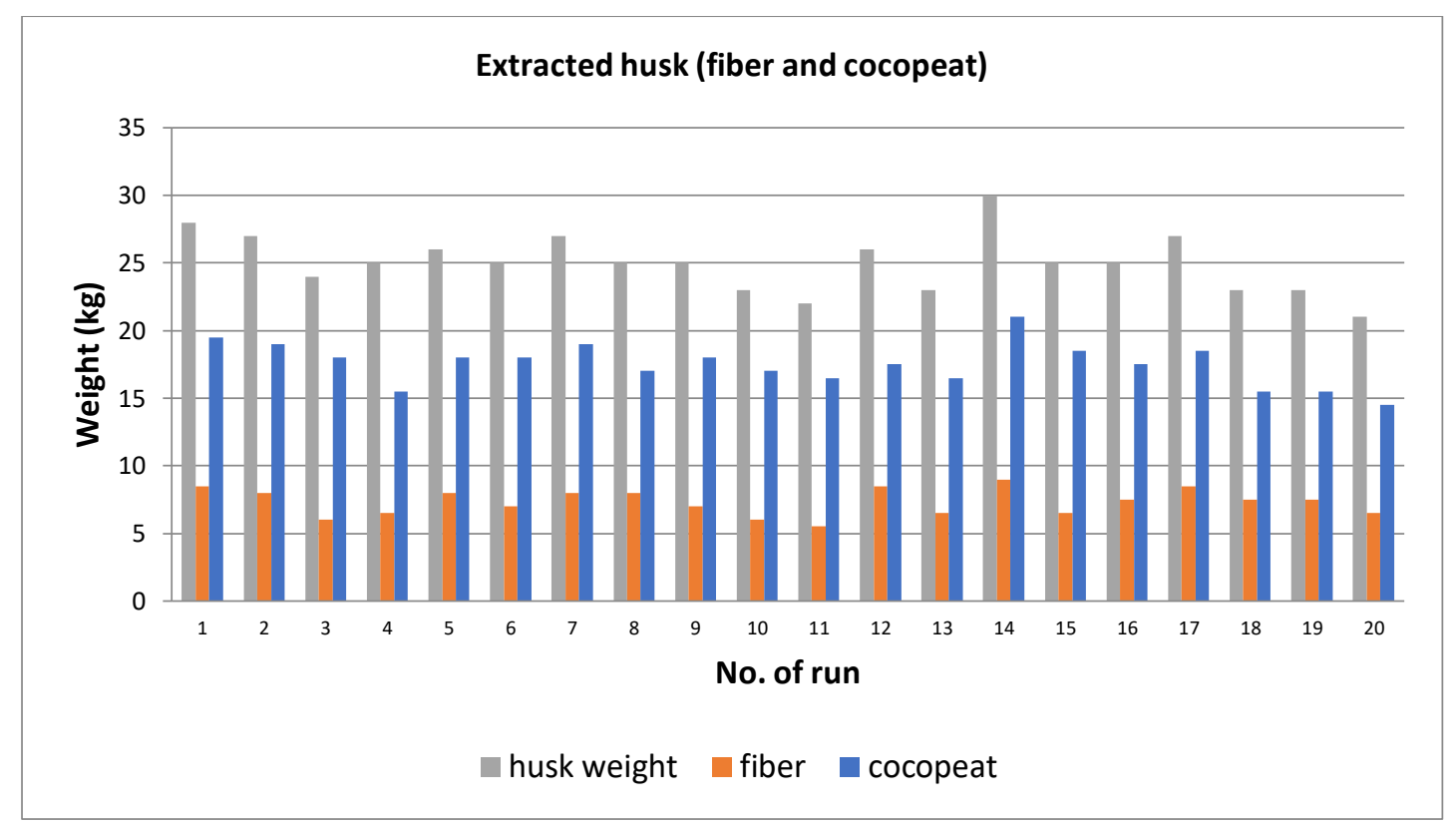

Figure 9. Result of product ratio of fiber and cocopeat after extraction process.

\subsection{Percentage of cocopeat in fiber}

The fiber from the extractor was filtered by using the rotary screener to extract the remaining cocopeat in the fiber. Results of the screening process are shown in Table 1 . The average value of cocopeat in the fiber was $2.8 \%$ only and the picture of fiber before screening process was displayed in Figure 10.

Table 1. Results of product ratio for extracted fiber after filtered via rotary screener.

\begin{tabular}{ccccc}
\hline Sample & $\begin{array}{l}\text { Extracted fiber } \\
\text { weight }(\mathbf{k g})\end{array}$ & $\begin{array}{l}\text { Weight of cocopeat in } \\
\text { fiber (kg) }\end{array}$ & $\begin{array}{l}\text { \% } \\
\text { cocopeat } \\
\text { in fiber }\end{array}$ & \% fiber \\
\hline 1 & 8.5 & 0.2 & 2.4 & 97.6 \\
2 & 8 & 0.19 & 2.4 & 97.6 \\
3 & 6 & 0.18 & 3.0 & 97.0 \\
4 & 6.5 & 0.19 & 2.9 & 97.1 \\
5 & 8 & 0.24 & 3.0 & 97.0 \\
6 & 7 & 0.23 & 3.3 & 96.7 \\
7 & 8 & 0.22 & 2.8 & 97.3 \\
8 & 8 & 0.25 & 3.1 & 96.9 \\
9 & 7 & 0.23 & 3.3 & 96.7 \\
10 & 6 & 0.16 & 2.7 & 97.3 \\
11 & 5.5 & 0.17 & 3.1 & 96.9 \\
12 & 8.5 & 0.2 & 2.4 & 97.6 \\
13 & 6.5 & 0.18 & 2.8 & 97.2 \\
14 & 9 & 0.27 & 3.0 & 97.0 \\
15 & 6.5 & 0.17 & 2.6 & 97.4 \\
16 & 7.5 & 0.18 & 2.4 & 97.6 \\
17 & 8.5 & 0.19 & 2.2 & 97.8 \\
\hline
\end{tabular}




\begin{tabular}{ccccc}
\hline Sample & $\begin{array}{l}\text { Extracted fiber } \\
\text { weight (kg) }\end{array}$ & $\begin{array}{l}\text { Weight of cocopeat in } \\
\text { fiber (kg) }\end{array}$ & $\begin{array}{l}\text { \% } \\
\text { cocopeat } \\
\text { in fiber }\end{array}$ & \% fiber \\
\hline 18 & 7.5 & 0.2 & 2.7 & 97.3 \\
19 & 7.5 & 0.25 & 3.3 & 96.7 \\
20 & 6.5 & 0.19 & 2.9 & 97.1 \\
& Average & & $\mathbf{2 . 8}$ & $\mathbf{9 7 . 2}$ \\
\hline
\end{tabular}

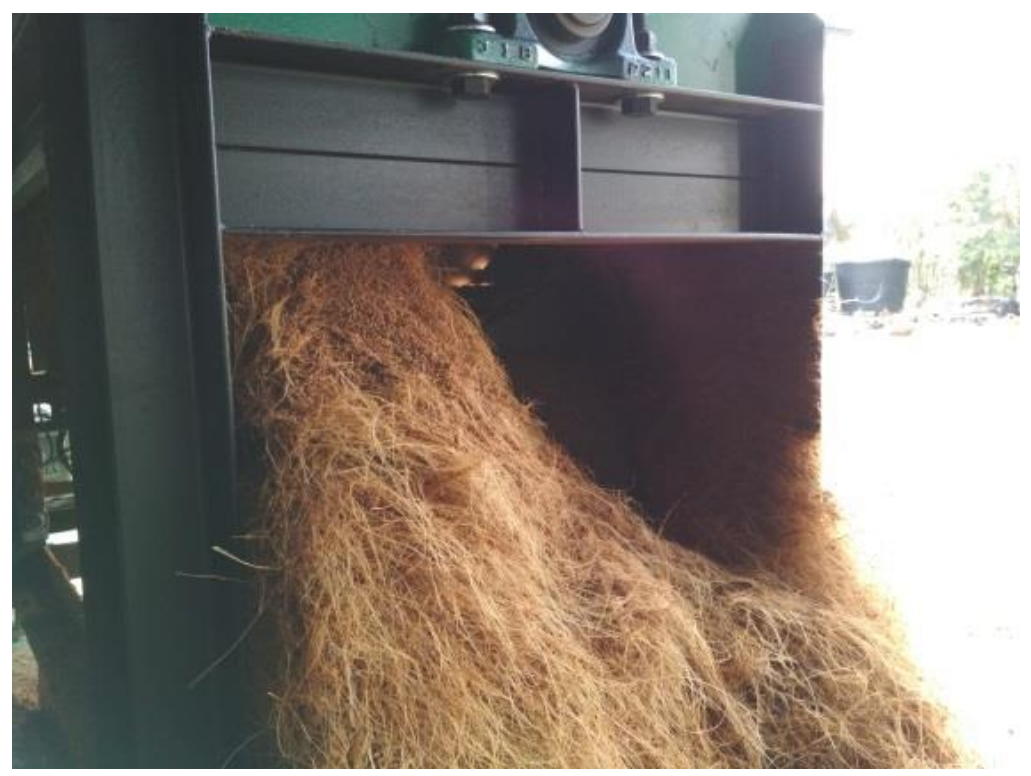

Figure 10. Extracted fiber before screening process.

\subsection{Cost of operation}

The power consumption and cost of operation were calculated based on tariff provided by local supplier as shown in Table 2 .

Table 2. Tariff rates for the domestic consumer.

\begin{tabular}{|c|c|c|}
\hline Tariff A-Domestic Tariff & Unit & Rates (sen) \\
\hline For the first $200 \mathrm{kWh}(1-200 \mathrm{kWh})$ per month & sen/kWh & 21.8 \\
\hline For the next $100 \mathrm{kWh}(201-300 \mathrm{kWh})$ per month & sen $/ \mathrm{kWh}$ & 33.40 \\
\hline For the next $300 \mathrm{kWh}(301-600 \mathrm{kWh})$ per month & sen/kWh & 51.60 \\
\hline For the next $300 \mathrm{kWh}(601-900 \mathrm{kWh})$ per month & sen/kWh & 54.60 \\
\hline For the next kWh (901 kWh onwards) per month & sen/kWh & 57.10 \\
\hline
\end{tabular}

(Source: Tenaga Nasional Berhad, 2014)

Table 3 showed operation cost of the processing system for young coconut husk extractor for a month (22 days operation for 8 hours/day). The operation cost was quite cheap which was RM 668.70/month. 
Table 3. Operation cost of the processing system for young coconut husk extractor.

\begin{tabular}{cccccc}
\hline Machine & $\begin{array}{c}\text { Power, } \\
(\mathbf{k W})\end{array}$ & $\begin{array}{c}\text { Tariff }(\mathbf{R M} / \mathbf{k W j a m}) \\
\text { or SFC(diesel) }\end{array}$ & $\begin{array}{c}\text { Operatio } \\
\mathbf{n}(\mathbf{h r})\end{array}$ & $\begin{array}{c}\text { Operation } \\
\text { cost/day }\end{array}$ & $\begin{array}{c}\text { Operation } \\
\text { cost/month }\end{array}$ \\
\hline $\begin{array}{c}\text { Chopping Machine } \\
\text { Young coconut husk }\end{array}$ & 1.5 & 0.218 & 8 & RM 2.62 & RM 57.55 \\
extractor (diesel) & 6.8 & RM 2.82 & 8 & RM 22.55 & RM 496.04 \\
$\begin{array}{c}\text { Rotary screener } \\
\text { Conveyor 1 }\end{array}$ & 0.75 & 0.218 & 8 & RM 1.31 & RM 28.78 \\
Conveyor 2 & 0.75 & 0.218 & 8 & RM 1.31 & RM 28.78 \\
Conveyor 3 & 0.75 & 0.218 & 8 & RM 1.31 & RM 28.78 \\
& 0.75 & 0.218 & 8 & RM 1.31 & RM 28.78 \\
& Total & & & RM 30.40 & RM 668.70 \\
\hline
\end{tabular}

\subsection{Machine investment cost and profit gained}

Table 4 showed a processing system for young coconut husk early cost for each machine. Total cost to set up all the machines was RM 60,000.

Table 4. Machine early cost.

\begin{tabular}{cc}
\hline Machine & Price (RM) \\
\hline Chopping Machine & 11,000 \\
Conveyor 1 & 5000 \\
Young coconut husk extractor & 25,000 \\
Conveyor 2 & 5000 \\
Conveyor 3 & 5000 \\
Rotary screener & 9,000 \\
TOTAL & $\mathbf{6 0 , 0 0 0}$ \\
\hline
\end{tabular}

Table 5 showed profit gain in a month by considering this processing system produce $350 \mathrm{~kg} / \mathrm{h}$ of fiber and cocopeat. Material cost was RM 0.20/kg while considering wage for workers RM $0.20 / \mathrm{kg}$ for fiber and RM $0.30 / \mathrm{kg}$ for cocopeat. Total monthly income for machines owner was RM 52, 923.30.

Table 5. Nett income for machine owner.

\begin{tabular}{|c|c|c|c|}
\hline & Fiber & Cocopeat & Monthly (RM) \\
\hline Monthly sales (RM) & $22,176.00$ & $60,368.00$ & $82,544.00$ \\
\hline Raw material cost (kg) & 61,6 & 0.00 & $(12,320.00)$ \\
\hline \multicolumn{3}{|c|}{ Machines operation cost } & $(668.70)$ \\
\hline Wage for workers & $3,696.00$ & $12,936.00$ & $(16,632.00)$ \\
\hline \multicolumn{3}{|c|}{ Nett income } & RM 52,923.30 \\
\hline
\end{tabular}

Return of investment (ROI) for this processing system was $88.21 \%$ which was very high and it was good to invest on these machines. 


\section{Conclusion}

Development of young coconut husk processing machine was necessary to enhance the agro-waste to value added product and to avoid environmental pollution from the abandoned young coconut husk. This machine was capable to process $350.79 \mathrm{~kg} / \mathrm{h}$ coconut husk in average which contains $70 \%$ of cocopeat and $30 \%$ of fiber. Utilization of rotary screener has improved the extraction by $2.8 \%$ cocopeat contains in the fiber.

The ROI was high and it was very good for farmers or entrepreneurs to take this technology. Therefore, processing of the young coconut husk by using these entire processing machines developed by MARDI was capable of producing quality value-added products and gain high income to farmers or entrepreneurs. For further research, the input material for the drying process can be improved instead of sunlight drying to reduce time consumption.

Supplementary Materials: The following are available online at http://www.journals.hhpublisher.com/index.php/AAFRJ//xxx/s1, Figure S1: title, Table S1: title.

Funding: This work was funded by project under the code of P-RM 413.

Acknowledgments: The authors would like to gratefully acknowledge MARDI for funding this project. The appreciation also extended to Mr. Kamil Zolkafli, Ms. Siti Ashah Abdul Rahim, Mr. Hakimi Zulkifli, and Mr. Mohd Syukri Hassan for their assistance during machine evaluation. My gratitude as well to others either directly or indirectly involved in the development of young coconut husk processing machine.

Conflicts of Interest: The authors declare no conflict of interest.

\section{References}

Christoper J. B. (2018, August 7-9). Implementation of coconut policies and initiatives: The real challenges to empower the industry. National Coconut Conference, Ipoh Perak.

Jabatan Pertanian Semenanjung Malaysia. (2018). Booklet statistic tanaman (sub-sektor tanaman makanan) 2018 [PDFfile]. Retrieved from http://www.doa.gov.my/index/resources/aktiviti_sumber/sumber_awam/maklumat_pertanian/perangkaan_tanaman/ booklet_statistik_tanaman_2018.pdf

Mani S., Tabil L. G. \& Sokhansanj S. (2004). Grinding performance and physical properties of wheat and barley straws, corn stover and switchgrass. Biomass and Bioenergy, 27(4), 339-352.

Mohd Hafizudin Z., Mohd Zaffrie M. A., Nor Amna A'liah M. N., et al. (2016). Kajian potensi dan kecenderungan pengguna terhadap kelapa segar dan Produk Makanan Berasaskan Kelapa (PMBK) di Malaysia, Laporan Kajian Sosioekonomi 2016.

Mohd Rashid R., Nor Amna A’liah M.N., Mohd Hafizudin Z. \& Mohd Dainori M.S. (2016). Potensi pembangunan industri kelapa negara dari perspektif rantaian nilai, Laporan Kajian Sosioekonomi 2016.

Mohd Zaffrie, M.A., Mohd Hafizudin Z. \& Azahar H. (2018). The market potential of non-food coconut-based products in Malaysia, National Coconut Conference, 7-9 August 2018, Ipoh Perak. eISBN 978-967-936-663-1

Onwuka U.N. \& Nwachukwu G. (2013). Grain size and heat source effect on the drying profile of cocoa beans. Nigerian Journal of Technology (NIJOTECH), Vol. 32. No. 3, pp. 417-423, ISSN: 1115-8443

Tafsir S. \& Mohd Hafizudin Z. (2018, August 7-9). Industry outlook and consumer preference for fresh and processed coconut products. National Coconut Conference, Ipoh Perak. 
Tenaga Nasional Berhad. (2018). Electricity tariff schedule [PDF file]. Retrieved from https://www.tnb.com.my/assets/files/Tariff_Rate_Final_01.Jan.2014.pdf

Wan Mohd Aznan W.A., Mohd Shahmihaizan M.J., Md Akhir H., et al. (2019, March 21). Evaluation of performance for young coconut husk processing machine and its product quality. Konvensyen Kebangsaan Kejuruteraan Pertanian Dan Makanan, Wisma Tani, Kementerian Pertanian Malaysia, Putrajaya. 